\title{
Pembuatan Configurable Payroll Software Untuk Meningkatkan Keleluasaan Saat Pengembangan Sistem Penggajian
}

\author{
Susana Limanto ${ }^{1 *}$, Ellysa Tjandra $^{2}$, Dionisius Dwi Putra $^{3}$ \\ 1,2,3Program Studi Teknik Informatika, Universitas Surabaya, Surabaya, Jawa Timur \\ Email: ${ }^{1 *}$ susana@staff.ubaya.ac.id, ${ }^{2}$ ellysa@staff.ubaya.ac.id, ${ }^{3}$ s160415019@student.ubaya.ac.id \\ (Naskah masuk: 1 Des 2020, direvisi: 19 Des 2020, 15 Jan 2021, diterima: 18 Jan 2021)
}

\begin{abstract}
Abstrak
Aturan dan komponen penggajian dari setiap perusahaan berbeda-beda disesuaikan dengan kondisi perusahaan. Aturan penggajian yang telah ditetapkan seringkali mengalami perubahan akibat adanya perubahan peraturan pemerintah ataupun kebijakan perusahaan. Hal tersebut mengakibatkan program penggajian yang digunakan oleh perusahaan perlu disesuaikan. Penyesuaian dapat dilakukan dengan memanggil pengembang program sehingga membutuhkan waktu yang relatif lebih lama dan biaya yang lebih besar. Untuk mengatasi permasalahan yang ada, dikembangkan sebuah program penggajian yang dapat dikonfigurasi sendiri oleh pengguna sistem sehingga tidak perlu memanggil pengembang program. Uji coba dilakukan dengan menggunakan metode black box testing dan simulasi. Pengujian dengan black box testing dilakukan dengan menggunakan berbagai macam skenario untuk mewakili setiap kemungkinan output dan mencocokkan hasilnya dengan desain yang telah dirancang sebelumnya. Setelah pengujian dengan black box testing berhasil, pengujian dilanjutkan dengan simulasi. Simulasi dilakukan dengan cara menerapkan fitur konfigurasi pada 3 buah sistem penggajian dari 3 jenis perusahaan yang berbeda. Hasil simulasi menunjukkan bahwa fasilitas konfigurasi pada sistem penggajian memungkinkan program yang dikembangkan memenuhi kebutuhan berbagai macam sistem penggajian dari setiap responden dan memudahkan pengguna dalam mengatur setiap faktor dan komponen penggajian seperti lembur, tunjangan dan potongan yang akan digunakan dalam sistem penggajian perusahaan tersebut. Hal ini menunjukkan adanya kemudahan dalam pengembangan sistem penggajian di kemudian hari secara mandiri sehingga dapat menghemat waktu dan biaya.
\end{abstract}

Kata Kunci: sistem penggajian, configurable, fleksibel, komponen gaji, customized system.

\section{Configurable Payroll Creation Software to Increase Flexibility in Payroll System Development}

\begin{abstract}
The payroll system policy of each company varies according to company conditions. Payroll policies that have been established often change due to changes in government regulations or company policies. This causes the payroll software used by the company needs to be adjusted. Adjustment can be done by contacting the software developer so that it takes a relatively longer time and costs more. To solve the existing problem, a payroll program was developed which could be configured by system users so that they did not need to contact the software developer. Testing was done using black box testing and simulation methods. Black box testing was applied using various scenarios to represent each possible output and matched the results with a previously design. After black box testing was done successfully, the test was continued with simulation. The simulation was done by applying the configuration feature to 3 payroll systems from 3 different business fields. The simulation results showed that the configuration facility in the payroll system allowed the software to meet the needs of various payroll systems of each respondent and maked it easier for users to manage each factor and component of payroll systems such as overtime, allowances and deductions to be used in the payroll system. The test results showed that there was ease in developing a payroll system at a later date independently so that it could save time and money.
\end{abstract}

Keywords: payroll system, configurable, flexible, payroll components, customized system. 


\section{PENDAHULUAN}

Penggajian merupakan sebuah sistem yang pasti ada pada setiap usaha yang mempekerjakan karyawan [1]. Aturan penggajian dibuat dengan berpedoman pada peraturan pemerintah yang berlaku [2] dan kondisi perusahaan. Adanya peraturan pemerintah yang baru ataupun perubahan terhadap kebijakan perusahaan seringkali mempengaruhi aturan penggajian yang ada sehingga perlu dilakukan penyesuaian. Penyesuaian dapat berupa perubahan bobot ataupun penambahan atau pengurangan komponen penggajian.

Banyaknya karyawan dan komponen penggajian mendorong perusahaan untuk mengembangkan sistem informasi penggajian berbasis komputer [3, 4]. Adanya sistem informasi penggajian ini diharapkan dapat meningkatkan efisiensi khususnya efisiensi waktu dan tenaga $[1,5,6]$ serta mengurangi tingkat eror saat input data [7]. Namun kebanyakan sistem informasi penggajian yang telah dikembangkan disesuaikan dengan aturan penggajian yang saat ini berlaku di perusahaan tersebut. Akibatnya sistem informasi penggajian tersebut tidak dapat digunakan lagi apabila terjadi perubahan mendasar pada aturan penggajian yang berlaku saat ini dan tidak dapat digunakan di perusahaan lainnya yang mempunyai aturan penggajian yang berbeda. Sistem informasi penggajian seperti ini disebut Customized Payroll Information System.

Perubahan pada aturan penggajian menyebabkan sistem informasi penggajian yang ada perlu disesuaikan. Apabila penyesuaian hanya berupa perubahan bobot, biasanya hal tersebut dapat diatasi langsung oleh perusahaan yang menggunakan Customized Payroll Information System. Namun apabila penyesuaian berupa penambahan komponen penggajian, biasanya perusahaan perlu memanggil developer yang mengembangkan aplikasi sistem informasi penggajian perusahaan tersebut untuk melakukan penyesuaian terhadap aplikasi tersebut. Hal ini seringkali membutuhkan waktu yang relatif lebih lama dan biaya yang lebih besar

Konsep mengenai sistem yang dapat dikonfigurasi sudah banyak dikembangkan oleh para peneliti [8]. Contoh penerapan sistem yang dapat dikonfigurasi adalah Ground Test Sistem for the A400M Aircraft [9] dan penjualan retail [10]. Saat ini sistem yang dapat dikonfigurasi banyak dikembangkan karena sistem yang dapat dikonfigurasi memungkinkan pengguna untuk melakukan berbagai macam penyesuaian secara mandiri $[11,12]$, mengurangi kompleksitas produk dan dapat diterapkan secara luas kepada banyak pelanggan [13], dapat dikonfigurasi kapan saja [13, 14], dan mengurangi biaya untuk memanggil developer [14]. Salah satu kunci utama dalam membangun sistem yang dapat dikonfigurasi secara optimal adalah menentukan bagian dari sistem yang dapat dikonfigurasi dan model konfigurasi untuk bagian tersebut [14]. Salah satu pendekatan untuk menentukan bagian mana yang dapat dikonfigurasi adalah dengan mempelajari sekumpulan sistem akan akan dibangun menjadi sistem yang dapat dikonfigurasi [14].

Penelitian tentang sistem penggajian yang banyak dilakukan oleh para peneliti adalah Customized Payroll Information System. Apabila terjadi penyesuaian terhadap sistem penggajian, maka perlu memanggil developer untuk melakukan penyesuaian pada Customized Payroll Information System sehingga dibutuhkan waktu dan biaya yang tidak sedikit. Pada penelitian ini, dibangun sebuah sistem penggajian yang dapat dikonfigurasi sehingga perubahan terhadap sistem penggajian dapat dilakukan secara mandiri. Hasil penelitian ini bermanfaat bagi pemilik usaha maupun pengembang program. Bagi pemilik usaha, adanya sistem penggajian yang dapat dikonfigurasi dapat mengurangi waktu dan biaya apabila terjadi penyesuaian terhadap sistem penggajian karena tidak perlu memanggil pengembang program. Sedangkan bagi pengembang program, sistem penggajian yang dapat dikonfigurasi dapat diterapkan di berbagai bidang usaha sehingga program yang sama dapat dijual di banyak pemilik usaha sehingga mengurangi waktu pembuatan program dan meningkatkan keuntungan.

\section{METODOLOGI PENELITIAN}

Penelitian dilakukan mengikuti langkah-langkah Software Development Life Cycle (SDLC) model waterfall. Tahapan kegiatan yang dilakukan meliputi: analisis kondisi saat ini dan merumuskan kebutuhan sistem, desain, koding, dan uji coba. Setiap tahapan kegiatan dilakukan secara berurutan. Analisis dilakukan dengan cara mempelajari peraturan pemerintah terkait dengan penggajian karyawan, benchmarking terhadap 3 program keuangan khususnya fitur yang terkait dengan penggajian, dan mengevaluasi sistem penggajian dari 3 buah perusahaan. Peraturan pemerintah dan program keuangan yang digunakan untuk benchmarking diperoleh dari internet. Program keuangan yang digunakan untuk benchmarking adalah $M y O B$, Accurate, dan Karyaone di tahun 2019. Pada ketiga program ini akan dipelajari fitur-fitur yang disediakan terkait dengan konfigurasi komponen penggajian. Tahap analisis ini merupakan salah satu tahap kegiatan yang sangat penting karena dari tahap ini akan ditentukan konfigurasi apa saja yang perlu dilakukan pada sistem penggajian dan kemungkinan model konfigurasi yang biasanya dilakukan perusahaan. Penentuan apa saja yang perlu dikonfigurasi pada sebuah sistem penggajian akan mempengaruhi fleksibilitas dari program yang akan dikembangkan.

Kebutuhan sistem terkait dengan daftar komponen penggajian yang perlu dikonfigurasi dan kemungkinan model konfigurasi yang didapatkan pada tahap analisis digunakan sebagai dasar melakukan desain sistem. Ada 3 macam desain yang dilakukan, yaitu: data, proses, dan user interface. Desain data dibuat dengan menggunakan bantuan perangkat lunak Workbench yang nantinya disinkronisasi dengan phpMyAdmin pada saat tahapan koding. Sedangkan desain proses dibuat dengan bantuan flowchart. Selanjutnya, hasil desain diimplementasikan dalam bentuk program dengan menggunakan perangkat lunak PHP dengan framework Laravel.

Untuk memastikan bahwa program yang dikembangkan dapat memenuhi kebutuhan dari berbagai macam sistem penggajian, maka dilakukan uji coba. Uji coba yang dilakukan mencakup verifikasi dan validasi. Verifikasi dilakukan untuk 
memastikan bahwa program sudah berjalan sesuai dengan desain. Verifikasi dilakukan dengan metode black box testing, yaitu dengan membuat berbagai macam skenario untuk mewakili semua kemungkinan yang ada dan mengevaluasi output dari program untuk dicocokkan dengan desain yang telah dibuat sebelumnya. Apabila hasil verifikasi tidak berjalan sebagaimana mestinya maka akan dilakukan perbaikan dan verifikasi ulang. Selanjutnya dilakukan validasi untuk memastikan bahwa program yang dibuat dapat mengakomodasi berbagai macam sistem penggajian melalui konfigurasi yang disediakan. Validasi dilakukan dengan metode simulasi, yaitu menerapkan fitur konfigurasi dari program yang telah dibuat pada 3 buah sistem penggajian dari 3 jenis perusahaan yang berbeda. Perusahaan pertama bergerak dalam bidang shipping dan Marine supplier. Sedangkan perusahaan kedua bergerak dalam bidang Outsourching Management System dan perusahaan ketiga bergerak dalam bidang perawatan kulit dan rambut. Ketiga perusahaan mempunyai sistem penggajian yang berbeda. Diagram alur dari metodologi penelitian yang dilakukan dapat dilihat pada Gambar 1.

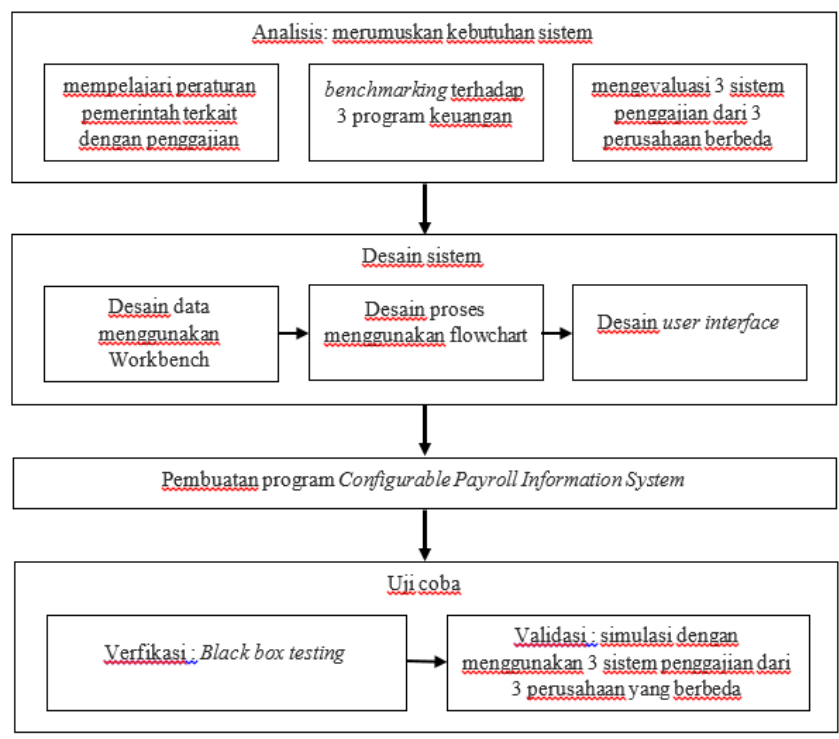

Gambar 1. Metodologi Penelitian

\section{CONFIGURABLE SYSTEM}

Configurable Systems adalah sebuah sistem yang memungkinkan pengguna untuk melakukan konfigurasi sistem tanpa bantuan dari pengembang program. Tujuan dibentuknya Configurable Systems adalah untuk memenuhi kebutuhan spesifik dari sebuah organisasi atau perusahaan secara mandiri. Konfigurasi sistem perlu dilakukan untuk melakukan penyesuaian dalam penggunaan teknologi informatika dalam suatu usaha. Soffer menyatakan bahwa konfigurasi merupakan sebuah proses penyesuaian dalam mengadaptasi suatu sistem untuk memenuhi kebutuhan perusahaan [15]. Jadi Configurable Enterprise System merupakan sebuah metode yang memudahkan perusahaan untuk mengatur atau menyesuaikan sistem perusahaan sesuai dengan kebutuhan perusahaan secara menyeluruh tanpa bantuan pengembang program. Adanya Configurable Enterprise System, memungkinkan perusahaan untuk menghemat biaya dan waktu pada saat diperlukan penyesuaian terhadap sistem yang ada.

Customized System merupakan sebuah sistem yang dikembangkan secara khusus untuk satu perusahaan tertentu sesuai dengan aturan yang diberlakukan perusahaan saat itu. Hal ini mengakibatkan sistem menjadi statis sehingga jika diperlukan suatu penyesuaian akibat adanya perubahan sistem, perusahaan harus memanggil pengembang program. Untuk memanggil pengembang program, perusahaan perlu mengeluarkan biaya dan kadang harus menunggu cukup lama. Beberapa perbedaan antara Configurable System dengan Customized System dapat dilihat pada Tabel 1 [16]. Struktur dasar software yang dikembangkan pada Configurable System pada dasarnya adalah sama sehingga waktu yang digunakan untuk pengembangan relatif lebih pendek dan dengan biaya yang relatif lebih murah dibandingkan pada Customized System di mana sistem harus dibangun dari awal disesuaikan dengan sistem perusahaan. Adanya fasilitas untuk melakukan konfigurasi sistem memungkinkan Configurable System diterapkan pada berbagai sistem perusahaan yang berbeda sehingga lebih bersifat global dan mudah disesuaikan jika ada perubahan dibandingkan dengan Customized System yang hanya berlaku untuk satu sistem tertentu.

Tabel 1. Configurable System vs Customized System

\begin{tabular}{lll}
\hline & $\begin{array}{c}\text { Configurable } \\
\text { System }\end{array}$ & $\begin{array}{c}\text { Customized } \\
\text { System }\end{array}$ \\
\hline $\begin{array}{l}\text { Pengembang } \\
\text { an software }\end{array}$ & $\begin{array}{l}\text { Waktu lebih } \\
\text { singkat dan biaya } \\
\text { lebih murah }\end{array}$ & $\begin{array}{l}\text { Biaya biasanya } \\
\text { mahal dan waktu } \\
\text { lebih lama }\end{array}$ \\
\hline $\begin{array}{l}\text { Ruang } \\
\text { lingkup } \\
\text { Sistem }\end{array}$ & Bersifat global & $\begin{array}{l}\text { Hanya berlaku } \\
\text { untuk perusahaan } \\
\text { tertentu }\end{array}$ \\
\hline $\begin{array}{l}\text { Pembaharuan } \\
\text { Sistem }\end{array}$ & $\begin{array}{l}\text { Lebih mudah dan } \\
\text { praktis }\end{array}$ & $\begin{array}{l}\text { Memakan waktu } \\
\text { dan biaya }\end{array}$ \\
\hline Biaya & $\begin{array}{l}\text { Biaya pengadaan } \\
\text { lebih rendah }\end{array}$ & $\begin{array}{l}\text { Biaya pengadaan } \\
\text { lebih tinggi }\end{array}$ \\
\hline
\end{tabular}

\section{SISTEM PENGUPAHAN}

Setiap karyawan mempunyai hak untuk mendapatkan upah yang nilainya sama dengan karyawan lainnya apabila pekerjaan yang dilakukan adalah sama atau setara. Upah yang diterima oleh seorang karyawan diberikan dalam bentuk uang sebagai imbalan atas pekerjaan dan/atau jasa yang dilakukan [17]. Upah yang diberikan kepada seorang karyawan harus diatur sedemikian hingga memberikan pendapatan yang dapat digunakan untuk memenuhi kebutuhan hidup seluruh anggota karyawan tersebut sewajarnya. Untuk itu, ada beberapa hal yang perlu diperhatikan dalam menyusun kebijakan terkait dengan penggajian, yaitu [17]:

1. Upah minimum yang harus diterima karyawan

2. Upah yang didapat karena bekerja lembur 
3. Upah yang dapat diterima walaupun tidak masuk kerja karena ada halangan

4. Upah yang tetap diterima atas hak menjalankan waktu istirahat kerja

5. Bentuk upah yang diberikan dan tata cara pembayarannya

6. Denda yang harus dibayar oleh karyawan karena lalai menjalankan kewajibannya

7. Potongan yang diberlakukan atas upah yang diterima oleh seorang karyawan

8. Hal-hal lainnya yang terkait dengan upah

9. Struktur dan skala pemberian upah secara proporsional

10. Pemberian pesangon

11. Aturan terkait dengan perhitungan besarnya pajak penghasilan yang harus dibayarkan karyawan

Penghasilan yang diterima oleh seorang karyawan agar memenuhi penghidupan yang layak dapat berupa upah dan non upah. Upah yang diberikan dapat berbentuk upah saja tanpa adanya tunjangan, upah pokok dan berbagai macam tunjangan tetap, ataupun upah pokok beserta berbagai macam tunjangan tetap dan tidak tetap. Apabila penghasilan yang diterima terdiri atas upah dan tunjangan, maka minimal $75 \%$ dari penghasilan harus berupa upah. Bentuk dari penghasilan non upah diantaranya adalah tunjangan yang diberikan pada hari raya keagamaan dan bonus kerja. Tunjangan Hari Raya (THR) keagamaan wajib diberikan secara terus menerus kepada karyawan yang telah bekerja minimal 1 bulan penuh [18]. THR ini wajib sudah diberikan kepada karyawan paling lambat 7 hari sebelumnya. Bonus kerja dapat diberikan kepada karyawan disesuaikan dengan keuntungan yang diperoleh perusahaan tersebut. Besarnya nilai bonus yang akan diberikan kepada karyawan ditetapkan dalam bentuk surat perjanjian kerja atau peraturan yang dibuat oleh perusahaan.

Penetapan besarnya upah dilakukan dengan berpedoman pada struktur dan skala pemberian upah secara proporsional. Struktur dan skala pemberian upah secara proporsional merupakan pemeringkatan kisaran nilai nominal upah mulai dari terendah sampai tertinggi atau sebaliknya untuk setiap golongan jabatan yang ada [19]. Ketentuan tentang pemberian upah secara proporsional yang ditetapkan oleh perusahaan wajib diberitahukan kepada seluruh karyawan perusahaan tersebut.

Setiap pekerja selain mendapatkan penghasilan juga dikenakan potongan. Minimal ada 3 komponen potongan yang saat ini dikenakan kepada karyawan, yaitu: iuran untuk Badan Penyelenggara Jaminan Sosial (BPJS) kesehatan, Pajak Penghasilan Pasal 21 (PPh 21), dan iuran untuk BPJS ketenagakerjaan [20].

BPJS Kesehatan adalah sebuah badan hukum yang didirikan oleh pemerintah Republik Indonesia untuk menjalankan program penjaminan kesehatan bagi seluruh masyarakat [21]. Setiap pemberi kerja wajib untuk mengikutsertakan dirinya dan para karyawannya menjadi peserta BPJS Kesehatan dengan cara membayar iuran yang telah ditetapkan untuk setiap bulannya [22]. Pembayaran iuran BPJS kesehatan untuk seorang karyawan dibagi menjadi 2, yaitu dibayar sebagian oleh pemberi kerja dan sebagian oleh karyawan yang bersangkutan disesuaikan dengan persentase yang telah ditentukan oleh pemerintah disesuaikan dengan jumlah tanggungan karyawan tersebut. Persentase pembayaran iuran BPJS Kesehatan oleh karyawan yang bersangkutan adalah sebesar $1 \%$ dari gaji atau upah yang diterima [23]. Sedangkan persentase pembayaran iuran BPJS Kesehatan oleh pemberi kerja adalah sebesar 4\% [23]. Batas tertinggi gaji atau upah per bulan yang digunakan sebagai dasar perhitungan besarnya iuran BPJS Kesehatan adalah 12 juta rupiah sedangkan batas terendahnya adalah upah minimum kabupaten/kota [23].

Pajak Penghasilan pasal 21 (PPh 21) adalah salah satu jenis pajak yang dikenakan pada penghasilan yang diterima oleh setiap orang baik dalam bentuk gaji/upah, tunjangan, honorarium maupun pembayaran lainnya [24]. Perhitungan PPh 21 dilakukan terhadap gaji atau upah yang diterima dalam kurun waktu 1 tahun. Ada beberapa komponen yang mempengaruhi perhitungan $\mathrm{PPh} 21$, yaitu [25]:

1. Pendapatan kotor/bruto berupa gaji pokok dan tunjangan

2. Pendapatan tidak rutin seperti bonus, THR, atau upah lembur

3. Iuran BPJS Kesehatan

4. Iuran BPJS ketenagakerjaan

5. Pengurang pendapatan kotor/bruto seperti biaya jabatan dan Penghasilan Tidak Kena Pajak (PTKP).

Biaya jabatan merupakan komponen biaya yang ditetapkan oleh pihak berwenang pada dinas perpajakan sebagai biaya yang dianggap dikeluarkan oleh setiap karyawan dalam melaksanakan pekerjaannya selama setahun. Biaya jabatan ditetapkan sebesar 5\% dari pendapatan bruto selama satu tahun dan setinggi-tingginya adalah sebesar lima ratus ribu sebulan [26].

PTKP merupakan pendapatan yang diterima oleh wajib pajak pribadi namun dibebaskan dari pembayaran $\mathrm{PPh}$ pasal 21 sesuai dengan ketentuan yang telah ditetapkan [27]. Jika pendapatan tahunan yang diterima oleh seorang wajib pajak melebihi ketentuan yang ada, maka yang bersangkutan wajib membayar pajak penghasilan atas kelebihan pendapatan tersebut sesuai dengan ketentuan. Besarnya tarif PTKP yang diberlakukan tahun 2019 adalah [27]:

- Besarnya tarif PTKP per tahun untuk setiap wajib pajak pribadi adalah Rp54.000.000.

- Besarnya tambahan PTKP per tahun untuk setiap wajib pajak yang mempunyai istri adalah Rp4.500.000.

- Besarnya tambahan PTKP per tahun untuk setiap tanggungan dari wajib pajak adalah Rp4.500.000. Yang dapat didaftarkan sebagai tanggungan adalah anggota keluarga yang sedarah dan semenda dalam garis keturunan lurus serta anak angkat. Maksimal jumlah tanggungan bagi seorang wajib pajak adalah 3 orang.

Sedangkan besarnya potongan pajak penghasilan adalah [28]:

- Lima persen dengan ketentuan: $0<$ penghasilan kena pajak per tahun $\leq 50$ juta

- Lima belas persen dengan ketentuan: 50 juta < penghasilan kena pajak per tahun $\leq 250$ juta

- Dua puluh lima persen dengan ketentuan: 250 juta < penghasilan kena pajak per tahun $\leq 500$ juta

- Tiga puluh persen dengan ketentuan: penghasilan kena pajak per tahun $>500$ juta 
BPJS Ketenagakerjaan adalah suatu badan hukum yang didirikan oleh pemerintah Republik Indonesia yang diperuntukkan bagi seluruh pekerja di negara Indonesia. Tujuan didirikannya BPJS Ketenagakerjaan adalah melindungi para pekerja di negara Indonesia dari dampak sosial ekonomi tertentu [29]. BPJS Ketenagakerjaan dulu dikenal dengan nama Jaminan Sosial Tenaga Kerja (Jamsostek). Mulai tanggal 1 Januari 2014, sesuai dengan UU No. 24 Tahun 2011 tentang BPJS, PT Jamsostek diubah menjadi BPJS Ketenagakerjaan. Ada 4 berbagai program yang disediakan oleh BPJS ketenagakerjaan, diantaranya adalah JHT dan JP. JHT merupakan program dari BPJS Ketenagakerjaan untuk menjamin keberlangsungan hidup karyawan di hari tua nanti. Manfaat yang diberikan oleh program ini adalah pengembalian atas akumulasi iuran yang telah dibayarkan oleh karyawan yang bersangkutan ditambah dengan hasil pengembangan dalam bentuk uang tunai. Sedangkan JP merupakan merupakan program dari BPJS Ketenagakerjaan sebagai bentuk jaminan sosial bagi penerimanya (peserta/ahli warisnya) untuk mempertahankan pemenuhan kebutuhan hidup yang layak. Manfaat yang diberikan oleh program ini adalah pemberian pendapatan dalam bentuk uang apabila peserta mengalami cacat tetap secara total, memasuki usia pensiun, atau meninggal dunia. Manfaat yang diberikan akan dibayar per bulan.

Ketentuan mengenai gaji/upah dari setiap perusahaan wajib ditinjau secara berkala. Peninjauan perlu dilakukan agar gaji/upah yang diterima oleh karyawan tetap dapat digunakan untuk memenuhi kebutuhan hidup secara layak. Selain itu, peninjauan gaji/upah juga perlu dilakukan untuk meningkatkan produktivitas kerja dari para karyawan perusahaan tersebut. Kemampuan dari perusahaan perlu diperhitungkan saat melakukan peninjauan gaji/upah.

\section{HASIL DAN PEMBAHASAN}

Agar program sistem penggajian yang dikembangkan dapat meningkatkan fleksibilitas bagi pengguna, maka perlu dilakukan perancangan model konfigurasi yang menyeluruh. Untuk itu dilakukan analisis dengan cara mempelajari peraturan pemerintah terkait dengan penggajian, mengevaluasi beberapa program yang mendukung sistem penggajian dan menerapkan konsep konfigurasi, dan mengevaluasi sistem penggajian dari 3 buah perusahaan. Berdasarkan hasil analisis dapat disimpulkan bahwa konfigurasi yang perlu dilakukan pada sistem penggajian meliputi data karyawan, presensi termasuk jam lembur, komponen tunjangan, dan komponen potongan. Pada data karyawan dapat ditentukan jabatan, golongan, jenis kelamin, maupun status pernikahan dari karyawan tersebut. Presensi dapat diatur mempengaruhi bonus, potongan ataupun tidak berpengaruh. Jam lembur juga dapat diatur bertahap disesuaikan dengan peraturan pemerintah yang berlaku ataupun aturan yang ditetapkan oleh perusahaan. Tunjangan dan potongan dapat dikembangkan macamnya disesuaikan dengan kebutuhan perusahaan. Selain itu, cara perhitungan setiap tunjangan dan potongan juga dapat disesuaikan dengan kebutuhan perusahaan. Sebagai contoh, tunjangan jabatan pada perusahaan tersebut hanya diberikan kepada para karyawan sesuai dengan jabatannya namun tunjangan transportasi akan diberikan kepada setiap karyawan sesuai dengan jumlah hari karyawan tersebut masuk kerja. Tabel 2 menunjukkan komponen yang dapat dikonfigurasi.

Tabel 2. Komponen Penggajian Yang Dikonfigurasi

\begin{tabular}{|c|c|}
\hline Komponen & Tipe Konfigurasi \\
\hline Jabatan & $\begin{array}{l}\text { - Ada/tidak } \\
\text { - Jika ada perlu dicatat macam-macam } \\
\text { jabatan yang ada, tunjangan dan } \\
\text { potongan yang tergantung pada jabatan. }\end{array}$ \\
\hline Golongan & $\begin{array}{l}\text { - Ada/tidak } \\
\text { - Jika ada perlu dicatat macam-macam } \\
\text { golongan yang ada }\end{array}$ \\
\hline Gaji pokok & $\begin{array}{l}\text { - Berdiri sendiri/tergantung } \\
\text { golongan/tergantung jabatan }\end{array}$ \\
\hline Presensi & $\begin{array}{l}\text { - Dicatat/tidak. } \\
\text { - Jika dicatat maka perlu ditentukan } \\
\text { tunjangan dan potongan yang tergantung } \\
\text { pada jumlah presensi/absensi. }\end{array}$ \\
\hline Jam lembur & $\begin{array}{l}\text { - Dicatat/tidak. } \\
\text { - Jika dicatat dan menambah penghasilan } \\
\text { maka perlu ditentukan hari lembur, jenis } \\
\text { lembur ( } 1 \text { jam pertama/1 jam kedua/ dan } \\
\text { seterusnya), dan rumus perhitungannya. }\end{array}$ \\
\hline Tunjangan & $\begin{array}{l}\text { - Ada/tidak. } \\
\text { - Jika ada perlu dicatat macam-macam } \\
\text { tunjangan yang ada, besarnya tunjangan } \\
\text { (nominal (Rp)/persentase terhadap gaji } \\
\text { pokok), waktu pembayarannya } \\
\text { (bulanan/non bulanan), dan status } \\
\text { (aktif/tidak). Bonus dimasukkan sebagai } \\
\text { tunjangan insidentil. }\end{array}$ \\
\hline Potongan & $\begin{array}{l}\text { - Ada/tidak. } \\
\text { - Jika ada perlu dicatat macam-macam } \\
\text { potongan yang ada, besarnya potongan } \\
\text { (nominal (Rp)/persentase terhadap gaji } \\
\text { pokok/persentase terhadap gaji bruto), dan } \\
\text { status (aktif/tidak). }\end{array}$ \\
\hline $\begin{array}{l}\text { Jenis } \\
\text { kelamin }\end{array}$ & Laki-laki/perempuan \\
\hline $\begin{array}{l}\text { Status } \\
\text { pernikahan }\end{array}$ & $\begin{array}{l}\text { Belum menikah/Menikah } 0 \\
\text { tanggungan/Menikah } 1 \text { tanggunggan/ } \\
\text { Menikah } 2 \text { tanggunggan/dan seterusnya }\end{array}$ \\
\hline
\end{tabular}

Daftar kebutuhan terkait dengan sistem penggajian yang fleksibel yang telah didefinisikan digunakan sebagai dasar untuk merancang sistem penggajian yang baru. Inti dari sistem penggajian yang baru adalah pada konfigurasi awal dari sistem penggajian. Pada konfigurasi awal ini, petugas yang berwenang dari perusahaan wajib menentukan komponen yang digunakan untuk penggajian serta struktur dan skala penggajiannya. Setelah konfigurasi awal selesai dilakukan, petugas yang berwenang dapat mengatur besarnya nilai setiap komponen gaji sebelum dapat melakukan proses perhitungan 
gaji untuk setiap periodenya. Hasil dari sistem penggajian ini adalah slip gaji dari setiap karyawan dan laporan penggajian untuk pimpinan. Desain proses secara global dari sistem penggajian yang dibuat dapat dilihat pada Gambar 2.

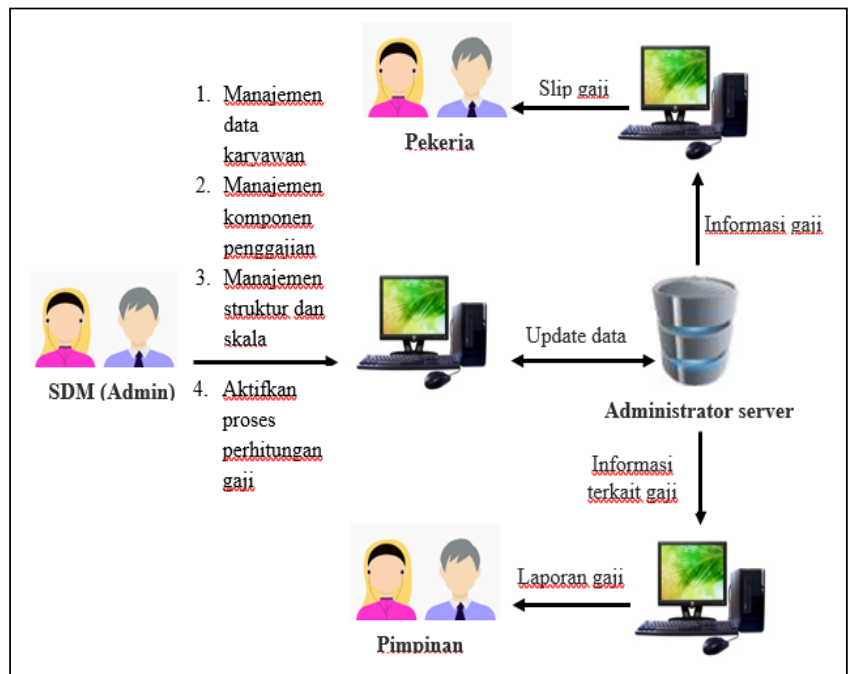

Gambar 2. Proses Configurable Payroll Information System

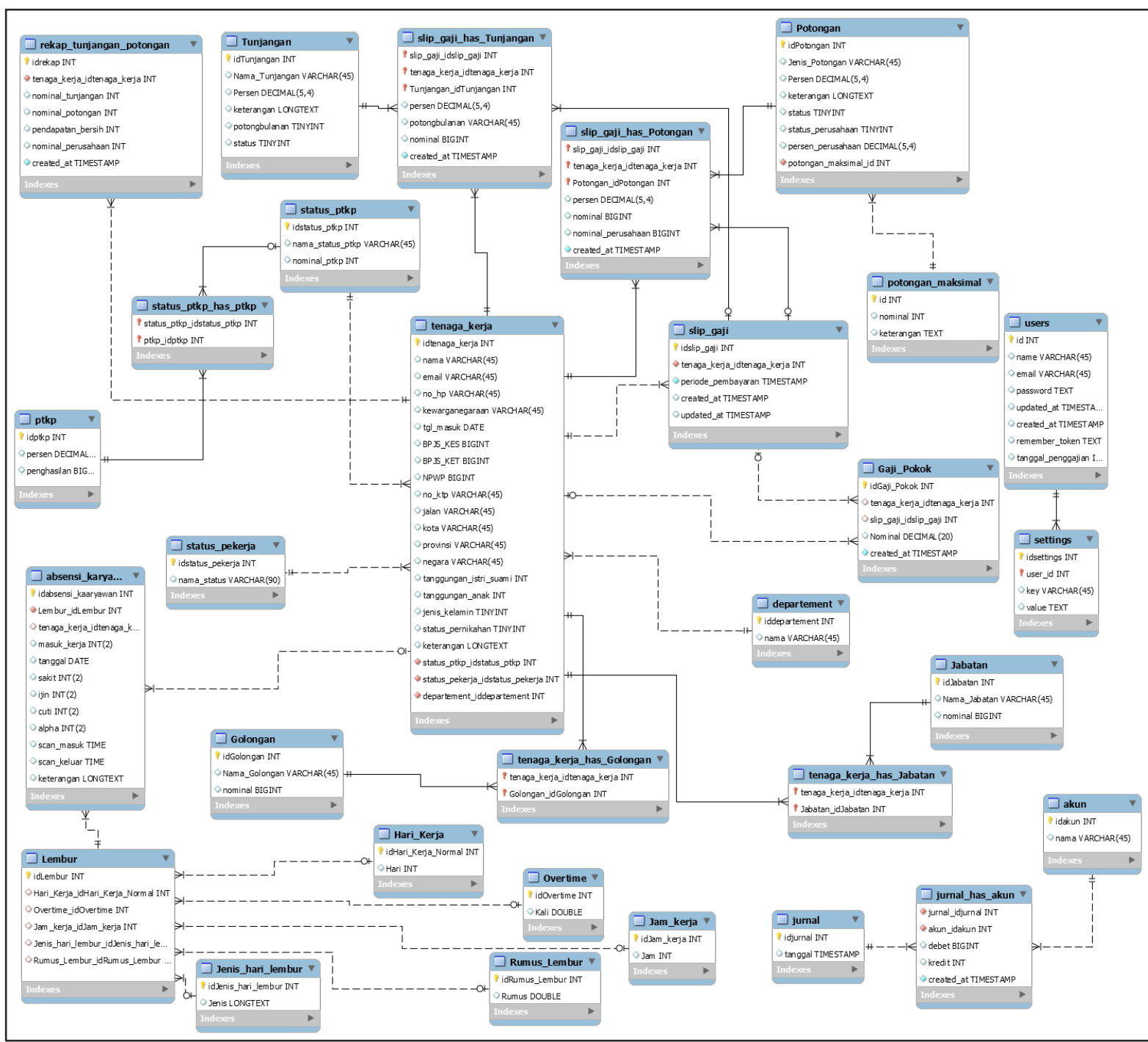

Gambar 3. Desain Data 
Selain desain proses juga dilakukan desain data sebagai tempat penyimpanan. Data didesain dengan mempertimbangkan semua kemungkinan konfigurasi yang telah ditetapkan. Hasil desain data dapat dilihat pada Gambar 3. Sebagian besar atribut dan entitas yang terlibat dalam desain data digunakan untuk mencatat kemungkinan konfigurasi yang dapat dilakukan.

Hasil desain kemudian diimplementasikan dalam bentuk program komputer "Configurable Payroll Information System". Hal yang pertama kali harus dilakukan saat menggunakan program ini adalah melakukan konfigurasi awal, yaitu pengaturan struktur dan skala upah, seperti yang terlihat pada Gambar 4.

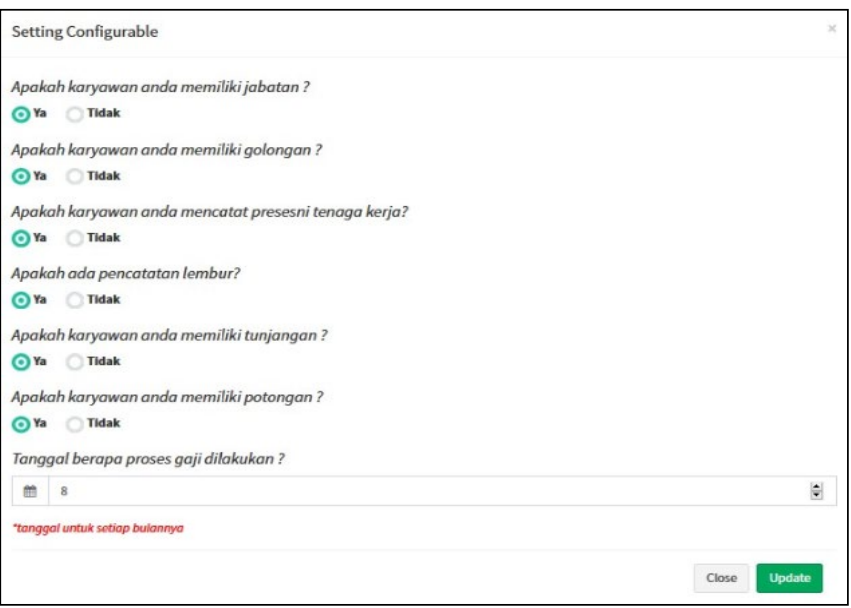

Gambar 4. Halaman Konfigurasi Awal

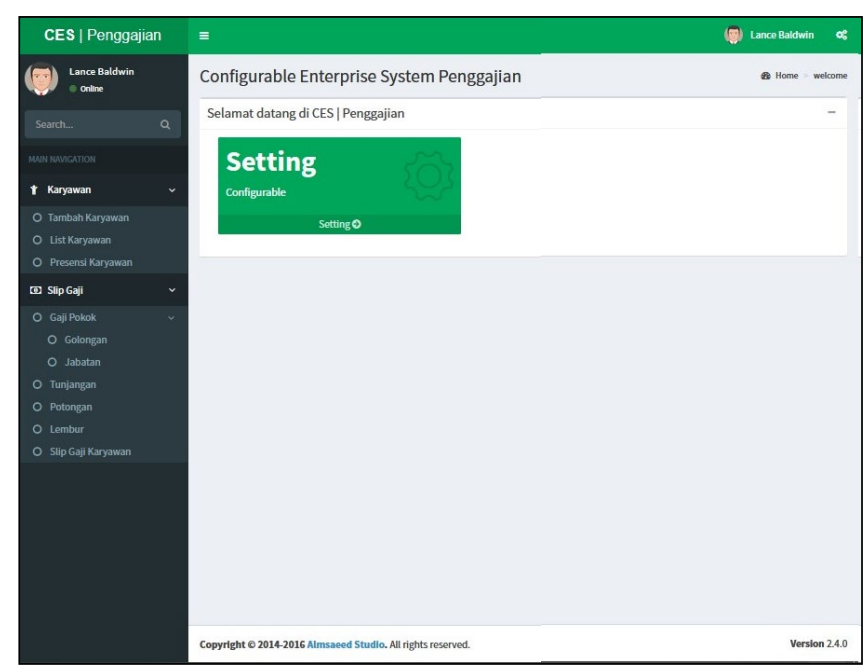

Gambar 5. Halaman Utama

Untuk itu, konfigurasi awal didesain wajib dilakukan pada saat pengguna pertama kali register, setelah itu, dapat disesuaikan dengan menggunakan menu Setting Configurable yang ada pada halaman utama seperti yang terlihat pada Gambar 5. Pada halaman konfigurasi awal, perusahaan diminta untuk menetapkan apakah sistem penggajian perusahaan tersebut mempertimbangkan jabatan, golongan, presensi, lembur, tunjangan, dan potongan atau tidak. Selain itu, petugas juga perlu menetapkan tanggal proses perhitungan gaji para pekerjanya. Menu faktor yang mempengaruhi gaji yang terlihat pada Gambar 5 disesuaikan dengan input yang dilakukan pada halaman konfigurasi awal. Sebagai contoh, apabila perusahaan tidak menetapkan golongan sebagai salah satu faktor yang mempengaruhi penggajian, maka menu golongan tidak akan muncul pada halaman utama.

Setelah konfigurasi awal selesai ditetapkan, petugas yang berwenang dapat dapat mulai menginputkan setiap komponen dari setiap faktor penggajian melalui menu yang tersedia di halaman utama. Gambar 6 menunjukkan halaman untuk menambahkan sebuah komponen penggajian dari kelompok tunjangan yang telah ditetapkan kontribusinya terhadap gaji pekerja adalah dalam bentuk persentase terhadap gaji pokok. Pada saat menambahkan tunjangan baru, petugas dapat mengisi besarnya tunjangan, menentukan periode pembayarannya, dan menambahkan keterangan jika diperlukan. Besarnya tunjangan dapat diatur dalam bentuk persentase terhadap gaji pokok (lihat Gambar 6) atau dalam bentuk nominal (dalam rupiah). Periode pembayaran dapat ditentukan bulanan atau non bulanan. Yang dimaksud dengan pembayaran non bulanan adalah tunjangan tersebut dibayarkan hanya pada saat-saat tertentu, seperti Tunjangan Hari Raya (THR) yang hanya dibayarkan mendekati hari raya keagamaan tertentu.

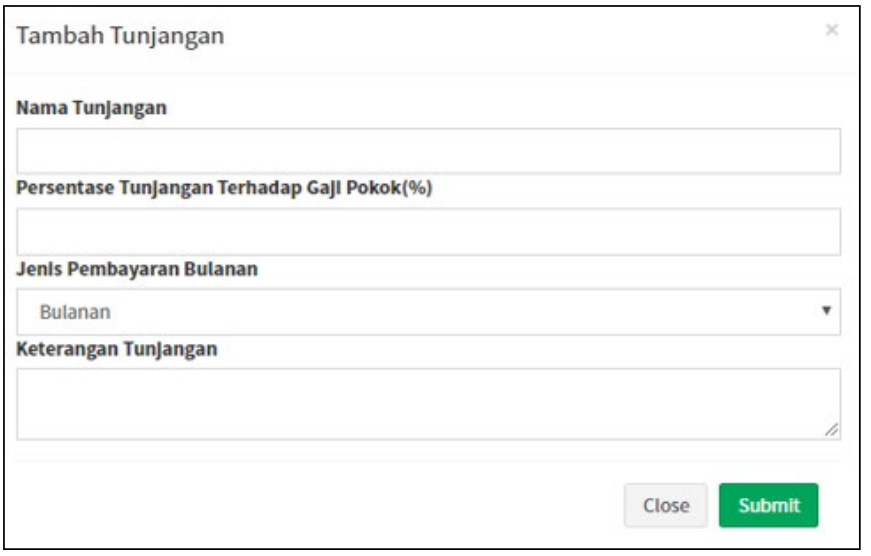

Gambar 6. Halaman Input Komponen Gaji - Tunjangan

Gambar 7 menunjukkan halaman untuk menambahkan sebuah komponen penggajian dari kelompok lembur. Melalui form ini, perusahaan dapat menginputkan cara perhitungan uang lembur dari pekerja, namun sebelumnya perusahaan perlu menginputkan terlebih dahulu standar jumlah hari kerja per minggu dan jumlah jam kerja per hari. Data yang digunakan dalam proses penggajian adalah data setelah tanggal proses penggajian periode sebelumnya.

Setelah semua data diinputkan, pada waktu yang telah ditentukan sistem akan melakukan proses perhitungan gaji para pekerja. Setelah proses perhitungan gaji selesai dilakukan oleh sistem, perusahaan wajib melakukan verifikasi terhadap hasil proses perhitungan gaji tersebut sebelum pekerja dapat melihat dan mencetak slip gaji periode tersebut secara mandiri. Contoh slip gaji dapat dilihat pada Gambar 8. Pekerja dapat melihat detail dari gaji yang diterimanya melalui slip gaji ini. 


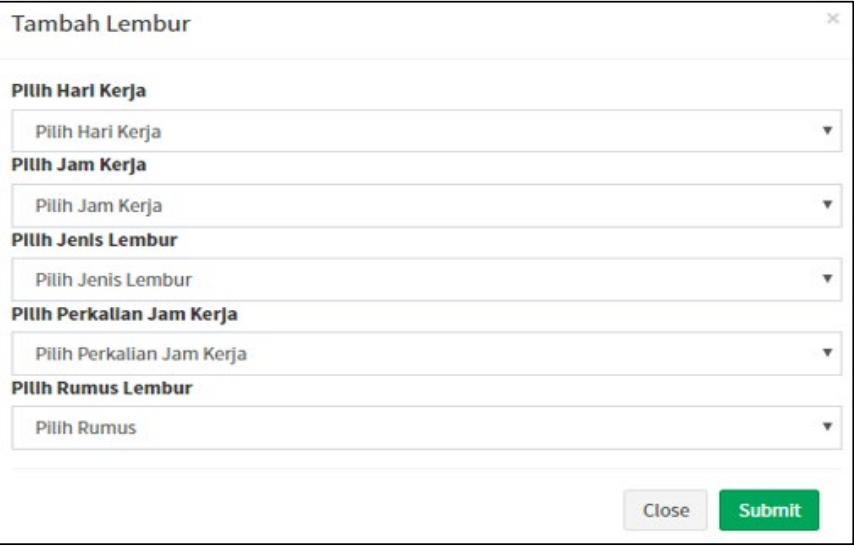

Gambar 7. Halaman Input Komponen Gaji - Lembur

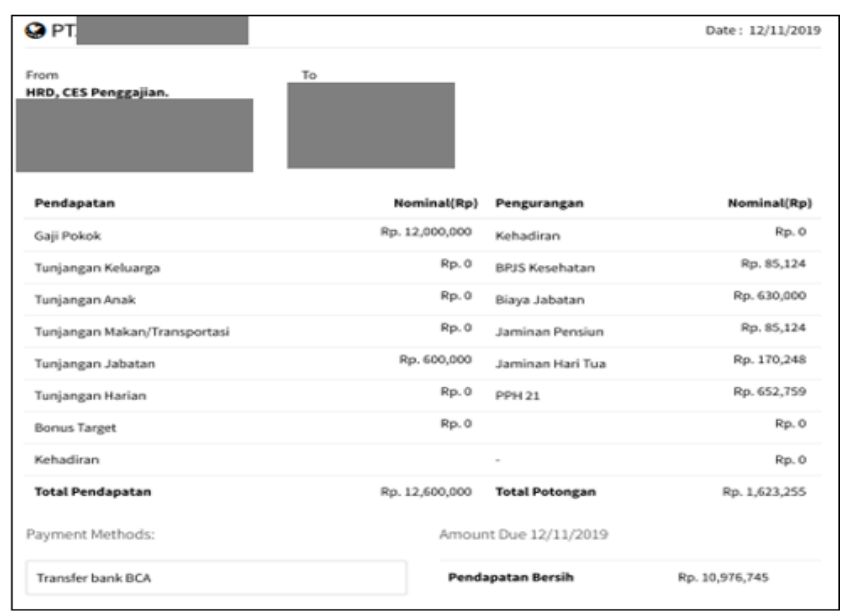

Gambar 8. Contoh Slip Gaji

Uji coba dengan metode simulasi dilakukan dengan cara menerapkan 3 buah sistem penggajian dari 3 jenis perusahaan yang berbeda pada program yang dibuat. Jenis perusahaan dan komponen serta tipe penggajian yang digunakan oleh ketiga perusahaan yang digunakan dalam uji coba simulasi dapat dilihat pada Tabel 3 .

Tabel 3. Data Uji Coba Simulasi

\begin{tabular}{ll}
\hline Jenis Perusahaan & Komponen dan Tipe Penggajian \\
\hline Shipping dan & - Gaji pokok (berdiri sendiri) \\
Marine supplier. & - Tunjangan jabatan (50\% gaji \\
& pokok) \\
& - Tunjangan konsumsi (Rp \\
& $22.750,-$ /hari masuk kerja) \\
& - Tunjangan harian (Rp 26.000,- / \\
& hari masuk kerja) \\
& - Bonus target (nominal (Rp)) \\
& - Potongan PPh 21. \\
& Data karyawan yang menjadi \\
& responden: laki-laki, menikah dan \\
& belum punya anak, jumlah hari \\
kerja = 20.
\end{tabular}

\begin{tabular}{|c|c|}
\hline $\begin{array}{l}\text { Outsourching } \\
\text { Management } \\
\text { System }\end{array}$ & $\begin{array}{l}\text { - Gaji pokok (berdiri sendiri) } \\
\text { - Bonus target (nominal(Rp)) } \\
\text { - Iuran pensiun (1,25\% gaji pokok) } \\
\text { - Iuran JHT (2\% gaji pokok) } \\
\text { - Biaya jabatan ( } 5 \% \text { total } \\
\text { pendapatan) } \\
\text { - Potongan PPh } 21 \\
\text { Data karyawan yang menjadi } \\
\text { responden: laki-laki, menikah dan } \\
\text { belum punya anak }\end{array}$ \\
\hline $\begin{array}{l}\text { Perawatan kulit dan } \\
\text { rambut }\end{array}$ & $\begin{array}{l}\text { - } \text { Gaji pokok (berdiri sendiri) } \\
\text { - Tunjangan makan dan } \\
\text { transportasi (Rp 12.000,- /hari } \\
\text { masuk kerja) } \\
\text { - Tunjangan jabatan (Nominal (Rp) } \\
\text { - supervisor : Rp 764.540,-) } \\
\text { - Tunjangan Insensif (Nominal } \\
\text { (Rp)) } \\
\text { - Iuran BPJS Kesehatan (1,212\% } \\
\text { gaji pokok) } \\
\text { - Iuran JHT (2,425\% gaji pokok) } \\
\text { - Iuran JP (1,212\% gaji pokok) } \\
\text { - Potongan PPh } 21 \\
\text { Data karyawan yang menjadi } \\
\text { responden: perempuan, menikah } \\
\text { dan mempunyai } 2 \text { anak, menjabat } \\
\text { sebagai supervisor }\end{array}$ \\
\hline
\end{tabular}

Uji coba dilakukan dengan cara menginputkan setiap komponen dan tipe penggajian dari setiap sistem penggajian responden dimulai dari responden pertama. Setelah itu dilakukan evaluasi terhadap hasil program, yaitu slip gaji. Untuk itu, dipilih 1 orang karyawan dari setiap perusahaan untuk dievaluasi slip gajinya. Pemilihan karyawan dari setiap perusahaan yang dijadikan responden dilakukan dengan menggunakan metode Simple Random Sampling. Hasil perhitungan setiap komponen gaji dari slip gaji yang dihasilkan oleh program akan dicocokkan dengan komponen gaji yang bersesuaian dari slip gaji karyawan yang diberikan oleh perusahaan. Setelah evaluasi hasil program dari responden 1 selesai, selanjutnya dilakukan penyesuaian program dengan sistem penggajian dari responden kedua. Simulasi untuk responden kedua dan ketiga dilakukan dengan cara yang sama dengan responden yang pertama.

Hasil uji coba dapat dilihat pada Tabel 4. Tabel 4 menunjukkan bahwa setiap komponen dan tipe penggajian dari semua perusahaan responden dapat diakomodasi oleh program yang dikembangkan. Hal ini dimungkinkan karena adanya fasilitas untuk melakukan konfigurasi terhadap komponen dan tipe penggajian yang ada. Hasil pencocokan antara slip gaji yang dihasilkan program dengan slip gaji yang diberikan oleh perusahaan responden 3 menunjukkan adanya perbedaan hasil perhitungan pada komponen potongan. Hal ini kemungkinan dikarenakan sebenarnya gaji yang diterima karyawan di 
perusahaan responden 3 sudah ditetapkan namun kemudian dipecah-pecah menjadi beberapa komponen yang persentasenya berupa bilangan irasional. Namun, saat menginputkan tipe penggajian dilakukan pembulatan sehingga hasilnya tidak sama. Hasil validasi selanjutnya dikonfirmasikan dengan pihak perusahaan responden. Pihak perusahaan menyatakan bahwa fasiltas konfigurasi yang disediakan oleh program memudahkan perusahaan untuk mengatur setiap komponen penggajian sehingga perusahaan tidak perlu memanggil developer jika terjadi penyesuaian pada sistem penggajian perusahan tersebut. Pada akhirnya, kondisi ini akan memberikan penghematan waktu dan biaya.

Tabel 4. Hasil Uji Coba Simulasi

\begin{tabular}{|c|c|c|}
\hline Perusahaan & $\begin{array}{c}\text { Penerapan Sistem } \\
\text { Penggajian } \\
\text { Perusahaan pada } \\
\text { Program yang } \\
\text { Dibuat } \\
\end{array}$ & $\begin{array}{c}\text { Ketelitian } \\
\text { Perhitungan } \\
\text { Setiap Komponen } \\
\text { Penggajian dari } \\
\text { Program } \\
\end{array}$ \\
\hline $\begin{array}{l}\text { Shipping dan } \\
\text { Marine } \\
\text { supplier. }\end{array}$ & $\begin{array}{l}\text { Program dapat } \\
\text { mengakomodasi } \\
\text { setiap komponen } \\
\text { dan tipe penggajian } \\
\text { perusahaan }\end{array}$ & $\begin{array}{l}\text { Hasil perhitungan } \\
\text { semua komponen } \\
\text { penggajian sudah } \\
\text { benar }\end{array}$ \\
\hline $\begin{array}{l}\text { Outsourching } \\
\text { Management } \\
\text { System }\end{array}$ & $\begin{array}{l}\text { Program dapat } \\
\text { mengakomodasi } \\
\text { setiap komponen } \\
\text { dan tipe penggajian } \\
\text { perusahaan }\end{array}$ & $\begin{array}{l}\text { Hasil perhitungan } \\
\text { semua komponen } \\
\text { penggajian sudah } \\
\text { benar }\end{array}$ \\
\hline $\begin{array}{l}\text { Perawatan } \\
\text { kulit dan } \\
\text { rambut }\end{array}$ & $\begin{array}{l}\text { Program dapat } \\
\text { mengakomodasi } \\
\text { setiap komponen } \\
\text { dan tipe penggajian } \\
\text { perusahaan }\end{array}$ & $\begin{array}{l}\text { Ada perbedaan } \\
\text { hasil perhitungan } \\
\text { komponen } \\
\text { potongan antara slip } \\
\text { gaji yang dihasilkan } \\
\text { program dengan } \\
\text { yang diberikan oleh } \\
\text { perusahaan }\end{array}$ \\
\hline
\end{tabular}

\section{KESIMPULAN}

Penyesuaian terhadap sistem penggajian perlu dilakukan secara berkala sesuai dengan peraturan pemerintah. Hal ini perlu dilakukan sebagai upaya untuk melakukan penyesuaian terhadap biaya atas kebutuhan hidup yang layak dan/atau untuk meningkatkan produktivitas para pekerja dengan mempertimbangkan kemampuan perusahaan. Bagi perusahaan yang sudah menggunakan program komputer untuk menangani administrasi penggajian, penyesuaian sistem penggajian dengan program yang ada seringkali membutuhkan waktu yang cukup lama dan biaya yang besar. Hal ini terjadi karena perusahaan biasanya tidak dapat melakukannya sendiri namun memanfaatkan jasa pengembang program.

Untuk mengatasi permasalahan yang ada, dikembangkan sebuah program penggajian yang fleksibel di mana setiap komponen penggajiannya dapat dikonfigurasi secara langsung dan mandiri oleh pihak perusahaan. Program yang dikembangkan diujicobakan dengan cara melakukan simulasi atas 3 sistem penggajian dari 3 macam bidang usaha. Pertama kali, program disimulasikan untuk sistem penggajian perusahaan responden pertama, kemudian program disesuaikan dengan mengubah konfigurasi komponen dan tipe penggajian yang terkait untuk mensimulasikan sistem penggajian perusahaan responden kedua. Terakhir, program disesuaikan lagi dengan sistem penggajian perusahaan responden ketiga dengan cara mengubah konfigurasi komponen dan tipe penggajian dari perusahaan responden kedua.

Hasil pengujian menunjukkan bahwa fleksibilitas dari program yang dibuat dalam mengatur komponen dan tipe penggajian dapat memenuhi kebutuhan dari setiap sistem penggajian responden yang berbeda-beda. Hal ini menunjukkan bahwa program dapat disesuaikan dengan berbagai macam sistem penggajian tanpa perlu mengubah program yang ada sehingga tidak perlu memanggil pengembang program. Program yang dapat disesuaikan dengan berbagai macam sistem penggajian secara mandiri menunjukkan kemudahan dalam melakukan penyesuaian komponen dan tipe penggajian apabila terjadi penyesuaian pada sistem penggajian perusahaan. Namun, hasil ujicoba menunjukkan adanya perbedaan perhitungan pada komponen potongan dari salah satu perusahaan responden. Hal ini terjadi karena tipe penggajian yang diinputkan pada program adalah hasil pembulatan bukan nilai yang sesungguhnya sehingga terjadi sedikit perbedaan hasil perhitungan.

\section{REFERENSI}

[1] Mahajan, K., Shukla, S. \& Soni, N. (2015). A Review of Computerized Payroll System. International Journal of Advanced Research in Computer and Communication Engineering, Vol. 4(1), pp. 67-70.

[2] Rusly, F.H., Ahmi, A., Talib, Y.Y.A. \& Rosli, K. (2019). Global Perspective on Payroll System Patent and Research: A Bibliometric Performance. International Journal of Recent Technology and Engineering (IJRTE), Vol. 8(2S2), pp. 148-157.

[3] Singh, A.V., Chaphekar, S.V. \& Sawant, Y.S. (2016). Automated Payroll System (A-PAY). International Journal of Modern Trends in Engineering and Research (IJMTER), Vol. 3(2), pp. 548 - 553.

[4] Gautam, P.R., Ragumani, S. \& Sharma, Y.K. (2010). A System for Payroll Management. Journal of Computer Science, Vol. 6(2), pp. 1531-1534.

[5] Siregar, M.U. \& Mahardika, D.E.K. (2018). An Implementation of Web-Based Payroll Information System in Universitas Proklamasi 45 Yogyakarta. International Journal on Informatics for Development (IJID), Vol. 7 (2), pp. 48-53.

[6] Suryanto. (2011). Design and Analysis: Payroll of Accounting Information System. CommIT, Vol. 5(1), pp. 24-26.

[7] Sandiwarno, S. (2018). Design Model of Payroll System Integrated with Attendance System at PT. XYZ. 
International Journal of Computer Techniques, Vol. 5(2), pp. 23-27.

[8] Siegmund, N., Grebhahn, A., Apel, S. \& Kästner, C. (2015). Performance-Influence Models for Highly Configurable Systems. ESEC/FSE 2015: Proceedings of the $10^{\text {th }}$ Joint Meeting on Foundations of Software Engineering, pp. 284 - 294. https://doi.org/10.1145/ 2786805.2786845 .

[9] Larios, D.F., Barbancho, J., Biscarri, F. \& Monedero, I. (2019). A Research Study for the Design of a Portable and Configurable Ground Test System for the A400M Aircraft. International Journal of Aerospace Engineering, Vol. 2019 , Article ID 5167575, pp. 1-16.

[10] Liliana, Absari, D.T., Benaly, F.B. (2020). Pengembangan Aplikasi Retail dengan Sistem Konfigurasi. Jurnal Teknika, Vol. 9(2), pp. 156-162.

[11] Qu, X. (2013). Testing of Configurable Systems (chapter 4), Advances in Computer, Vol. 89, pp. 141-162.

[12] Pereira, J.A., Acher, M., Martin, H. \& Jézéquel, J.M. (2020). Sampling Effect on Performance Prediction of Configurable Systems: A Case Study. ICPE '20: Proceedings of the ACM/SPEC International Conference on Performance Engineering, pp. 277-288.

[13] Arrow. (2020). Software Configurable Systems: Build Once - Adapt Often. Diakses dari https://www.arrow.com/en/research-andevents/articles/software-configurable-systems-buildonce-adapt-often, pada 17 Desember 2020.

[14] Nair, V., Menzies, T., Siegmund, N. \& Apel, A. (2017). Using Bad Learners to Find Good Configurations. ESEC/FSE 2017: Proceedings of the 2017 11th Joint Meeting on Foundations of Software Engineering, pp. 257-267. https://doi.org/10.1145/3106237.3106238.

[15] Soffer, P., Golany, B. \& Dori, D. (2003). ERP Modeling: a Comprehensive Approach. Information Systems, vol. 28(6), pp. 673-690.

[16] Vanek, C. (2016). Customized vs. Configurable Software Solutions: Which Should You Choose?. Diakses dari: https://npengage.com/nonprofittechnology/customized-vs-configurable-software-

solutions-which-should-you-choose/, pada 16 Juli 2020.

[17] Pemerintah Indonesia. (2015). Peraturan Pemerintah Republik Indonesia Nomor 78 Tahun 2015 tentang Pengupahan. Tambahan Lembaran Negara Republik Indonesia Nomor 5747. Jakarta.

[18] Menteri Ketengakerjaan RI. (2016). Peraturan Menteri Ketengakerjaan RI Nomor 6 Tahun 2016 Tentang Tunjangan Hari Raya Keagamaan Bagi Pekerja/Buruh di Perusahaan. Berita Negara Republik Indonesia Tahun 2016 Nomor 375. Jakarta.

[19] Menteri Ketengakerjaan RI. (2017). Peraturan Menteri Ketengakerjaan RI Nomor 1 Tahun 2017 Tentang Struktur Dan Skala Upah. Jakarta.
[20] Idris, M. (2020). 4 Komponen Pemotong Gaji Karyawan, Bakal Ditambah Tapera. Diakses dari https://money.kompas.com/read/2020/06/05/13120592 6/4-komponen-pemotong-gaji-karyawan-bakalditambah-tapera?page=all, pada 5 Juni 2020 .

[21] Pemerintah Indonesia. (2013). Peraturan Presiden Republik Indonesia Nomor 12 Tahun 2013 tentang Jaminan Kesehatan. Lembaran Negara Republik Indonesia Tahun 2013 Nomor 29. Jakarta.

[22] Pemerintah Indonesia. (2013). Peraturan Presiden Republik Indonesia Nomor 111 Tahun 2013 tentang Perubahan atas Peraturan Presiden Nomor 12 Tahun 2013 tentang Jaminan Kesehatan. Lembaran Negara Republik Indonesia Tahun 2013 Nomor 255. Jakarta.

[23] Pemerintah Indonesia. (2019). Peraturan Presiden Republik Indonesia Nomor 75 Tahun 2019 tentang Perubahan atas Peraturan Presiden Nomor 82 Tahun 2018 tentang Jaminan Kesehatan. Lembaran Negara Republik Indonesia Tahun 2019 Nomor 210. Jakarta.

[24] OnlinePajak. (2016). Cara Perhitungan PPh Pasal 21. PT Achilles Advanced Systems. Diakses dari https://www.online-pajak.com/tentang-pph21/caraperhitungan-pph-21, pada 3 Oktober 2020.

[25] OnlinePajak. (2019). Perhitungan PPh 21 Terbaru dengan PTKP 2019. PT Achilles Advanced Systems. Diakses dari https://www.online-pajak.com/tentangpph21/perhitungan-pph-21, pada 3 Oktober 2020.

[26] Kementerian keuangan RI - Direktorat Jenderal Pajak. (2016). Salinan Peraturan Direktur Jenderal Pajak No. PER-16/PJ/2016 tentang Pedoman Teknis Tata Cara Pemotongan, Penyetoran dan Pelaporan Pajak Penghasilan Pasal 21 dan/atau Pajak Penghasilan Pasal 26 sehubungan dengan Pekerjaan, Jasa, dan Kegiatan Orang Pribadi. Jakarta.

[27] OnlinePajak. (2019). PTKP 2019: Pengertian, Dasar Hukum dan Tarif PTKP 2019. PT Achilles Advanced Systems. Diakses dari https://www.onlinepajak.com/tentang-pajak-pribadi/ptkp-2019, pada 3 Oktober 2020.

[28] Pemerintah Indonesia. (2008). Undang-Undang Republik Indonesia Nomor 36 Tahun 2008 tentang Perubahan Keempat atas Undang-Undang Nomor 7 Tahun 1983 tentang Pajak Penghasilan. Lembaran Negara Republik Indonesia Tahun 2008 Nomor 133. Jakarta.

[29] Maulida, R. (2019). BPJS Ketenagakerjaan: 8 Hal PENTING Yang HARUS Anda Ketahui!. PT Achilles Advanced Systems. Diakses dari https://www.onlinepajak.com/tentang-pph21/bpjs-ketenagakerjaan, pada 3 Oktober 2020. 